\title{
Supervised Curricular Internship II: Experiences of the future chemistry teacher in
}

\section{remote education}

\author{
Estágio Curricular Supervisionado III: Experiências do futuro professor de química no ensino remoto \\ Pasantía Curricular Supervisada II: Experiencias del futuro profesor de química em la educación a distancia
}

Received: 11/13/2021 | Reviewed: 11/19/2021 | Accept: 11/20/2021| Published: 11/29/2021

Sérgio Luis Melo Viroli
ORCID: https://orcid.org/0000-0003-3982-1183
E-mail:viroli@ifto.edu.br
Nelson Pereira Carvalho
Instituto Federal de Educação, Ciências e Tecnologia do Tocatis, Brasil
ORCID: https://orcid.org/0000-0002-7637-1292
E-mail: nelson.pereira.carvalh@gmail.com
Gessica Hashimoto de Medeiros
Instituto Federal de Educação, Ciências e Tecnologia do Tocantins, Brasil
ORCID: https://orcid.org/0000-0002-9468-8154
E-mail:gessica.hm@gmail.com
Matheus Lisboa Ramos
Instituto Federal de Educação, Ciências e Tecnologia do Tocantins, Brasil
ORCID: https://orcid.org/0000-0002-1648-6733
Instituto Federal de Educação, Ciências e Tecnologia do Tocantins, Brasil
E-mail: matheus.lisboas13@gmail.com
João Vitor Vivan
ORCID: https://orcid.org/0000-0001-6826-6049
E-mail: jvitorvivan.jvv@gmail.com
Isac Alves Maia
Instituto Federal de Educação, Ciências e Tecnologia do Tocantins, Brasil
ORCID: https://orcid.org/0000-0002-7736-7412
Universidade Federal do Tocantins, Brasil
E-mail: isacalvesmaia@gmail.com

\begin{abstract}
The research analyzed the experiences of 20 (twenty) students developed in Remote Teaching (ER) in the 1st semester of 2021 after completing the Supervised Curricular Internship II. A qualitative and quantitative approach was carried out using a virtual questionnaire created on the Google Forms ${ }^{\circledR}$ digital platform, to investigate the choice of the Chemistry Degree course, conditions of access to digital technologies, pedagogical tools used during the internship, adversities encountered by these students during the realization of the internship and the contributions of the remote internship for the formation of the Graduate in Chemistry. After analyzing and tabulating the data, the research presented the following results: the students chose a degree because they like to teach and because of their insertion in the job market, they accessed digital technologies at home, using smartphones through a broadband service with good quality connection, used Google Meet ${ }^{\circledR}$, WhatsApp ${ }^{\circledR}$ and VLE virtual learning environment as pedagogical tools during the internship. Internet access, lack of knowledge in digital media and adaptation to remote classes were the adversities encountered during the internship. Learning and using different technological resources and digital platforms were the main contributions of the internship to the formation of decent people. The virtual remote internship enabled and provided opportunities for varied everyday experiences, promoting reflection on teaching work.
\end{abstract}

Keywords: Teacher training; Digital technology for education; Social isolation; Teaching learning.

\section{Resumo}

A pesquisa analisou as vivências de 20 (vinte) estudantes desenvolvidas no Ensino Remoto (ER) no $1^{\circ}$ semestre de 2021 após a conclusão do Estágio Curricular Supervisionado II. Foi realizada uma abordagem qualitativa e quantitativo utilizando um questionário virtual criado na plataforma digital Google Forms ${ }^{\circledR}$, para investigar a escolha do curso de Licenciatura em Química, condições de acesso as tecnologias digitais, ferramentas pedagógicas utilizadas durante o estágio, adversidades encontradas por esses discentes durante a realização do estágio e as contribuições do estágio remoto para formação do Licenciado em Química. Após análise e tabulação dos dados, a pesquisa apresentou os seguintes resultados: os discentes escolheram a licenciatura porque gostam de lecionar e pela inserção no mercado de trabalho, acessavam as tecnologias digitais em casa, utilizando smartphone através de um serviço de banda larga com boa qualidade de conexão, utilizaram o Google Meet ${ }^{\circledR}$, WhatsApp ${ }^{\circledR}$ e ambiente virtual de aprendizagem AVA como ferramentas pedagógicas durante o estágio. Acesso a internet, falta de conhecimento em meios digitais e 
adaptação as aulas remotas foram as adversidades encontradas durante a realização do estágio. A aprendizagem e utilização de diversos recursos tecnológicos e plataformas digitais foram as principais contribuições do estágio para a formação dos decentes. O estágio remoto virtual possibilitou e oportunizou experiências cotidianas variadas, promovendo a reflexão sobre trabalho docente.

Palavras-chave: Formação de professores; Tecnologia digitais para educação; Isolamento social; Ensino aprendizagem.

\section{Resumen}

La investigación analizó las experiencias de 20 (veinte) estudiantes desarrollados en Educación a Distancia (ER) en el 1er semestre de 2021 luego de completar la Pasantía Curricular Supervisada II. Se realizó un abordaje cualitativo y cuantitativo a través de un cuestionario virtual creado en la plataforma digital Google Forms ${ }^{\circledR}$, para investigar la elección del curso de Química, condiciones de acceso a tecnologías digitales, herramientas pedagógicas utilizadas durante la pasantía, adversidades encontradas por estos estudiantes durante el curso. de la pasantía y los aportes de la pasantía a distancia para la formación del Postgrado en Química. Luego de analizar y tabular los datos, la encuesta arrojó los siguientes resultados: los estudiantes optaron por la graduación porque les gusta enseñar y para ingresar al mercado laboral accedieron a las tecnologías digitales en casa, utilizaron teléfonos inteligentes a través de una buena conexión de calidad de servicio de banda ancha, utilizaron Google Meet ${ }^{\circledR}$, Entorno virtual de aprendizaje WhatsApp ${ }^{\circledR}$ y AVA como herramientas pedagógicas durante la pasantía. El acceso a Internet, el desconocimiento en medios digitales y la adaptación a las clases a distancia fueron las adversidades encontradas durante la pasantía. Aprender y utilizar diferentes recursos tecnológicos y plataformas digitales fueron los principales aportes de la pasantía a la formación de personas dignas. La pasantía virtual a distancia posibilitó y brindó oportunidades para variadas experiencias cotidianas, promoviendo la reflexión sobre la labor docente.

Palabras clave: Formación docente; Tecnología digital para la educación; Aislamiento social; Enseñanza aprendizaje.

\section{Introduction}

The Supervised Curricular Internship is an indispensable period for the development and evolution of the future teacher, as it is through the experience of the internship that the future teacher comes into contact with the praxis and conduct of the school (Bezerra \& Fonseca, 2018). In the experience of the school environment, future teachers will be able to reflect and verify their ideologies against the adversities imposed by the school reality (Viroli et al, 2021). The conception of theoretical and practical dimensions proposes a dynamic and progressive learning, assisted by professionals working in education, makes the Supervised Curriculum Internship in addition to a perception of values, meaning and (re)signifying knowledge as a gradual, systematic and formative project (Manara, Marzari, \& Ruppenthal, 2021).

The study of theoretical concepts and the experience of pedagogical practice can provide opportunities for the perspective of the teacher in training regarding the inseparability between theory and school practice perspectives (Bezerra \& Fonseca, 2018). Internship practices create spaces for experimentation and the development of new techniques, resources and tools aimed at improving the teaching and learning process. These practices are the genesis of the academic and professional experience of future teachers, where they will improve their methodologies and seek the new, in order to provoke in students, the will to acquire knowledge (Lorenson, Pereira, \& Mariano, 2020).

Teacher training courses should articulate theory and practice in an interdisciplinary way, promoting a solid foundation in the preparation of theoretical knowledge that should be taught by the future teacher. Critical thinking, interdisciplinary actions, organization, social engagement and a teaching practice based on the analysis of the future teacher's experience should also be conceived (Santos, \& Souza, 2020).

The realization of the face-to-face meetings of the supervised curricular internship discipline are essential occasions to make the connection between theory and practice. In these meetings, the internship advisors lead, create and problematize situations causing future teachers to reflect on their practice based on the experiences lived in the school environment during the internships, taking into account their concerns and desires. (Santos \& Souza, 2020).

The Regulation of the supervised curricular internship of on-site undergraduate courses of the Federal Institute of Education, Science and Technology of Tocantins [IFTO] informs that: 
The Supervised Curriculum Internship in the Licentiate Degree course should be an activity intrinsically articulated with the practice and activities of academic work, contributing to the formation of the teacher's identity as an educator and to the development of skills required in professional practice, especially regarding planning, organization, execution and evaluation of learning (IFTO, 2015, p. 23).

Also according to the regulation, the objectives of the Supervised Curricular Internship of the IFTO degree courses

are:

I - provide opportunities for the exercise of pedagogical competence, enabling the student to exercise their profession through the application of specific methods, procedures and resources in an internship situation in the Granting Units; II - enable the student to reflect on practice and its indissoluble articulation with theory, so that the training of basic education teachers can be consolidated with a view to social transformation based on the different realities felt by them in the Granting Units and from of the practices observed, experienced and constructed by different educational subjects; III - enable the student for professional initiation, emphasizing the pedagogical, technical, social, cultural and attitudinal character of the profession, through training in a work environment, emphasizing the education professional who is being trained; IV - reiterate to the student, when developing their Internship Activity Plan, the importance of socializing their experiences and reflecting in the classroom on their action and performance as an education professional; $\mathrm{V}$ - provide opportunities for the student, in the development of their programmed activities in the Granting Units, to demonstrate awareness of diversity, respecting differences in gender, age groups, social classes, differences related to special needs, those of an environmental, ecological, ethnic nature- racial, religious, sexual and affective, among others, as basic conditions for a culture of peace and quality of life (IFTO, 2015, pp. 23-24).

With the aggravation of the global public health crisis, in February 2020, the Ministry of Education, through Ordinance No. 343/MEC, instructs the replacement of classroom classes for classes in digital media, while the health crisis caused by COVID-19 lasts. (Souza, \& Ferreira, 2020). During 2020, Higher Education Institutions needed to adapt to the new dynamics resulting from the pandemic and all had to join the system through digital means with MEC Ordinance No. 544, of June 16, 2020 and Opinion CNE/ CP05/2020 to carry out non-face-to-face pedagogical activities in undergraduate courses (Souza, \& Ferreira, 2020).

With the interruption of classroom lectures, there was a need for teachers and students to migrate to online virtual reality, transposing methodologies and pedagogical practices from classroom learning to remote teaching (Moreira; Henriques, \& Barros, 2020). Remote Learning played an important role, standing out at the time of crisis, proposing changes, educational institutions, for the development of new forms of teaching and learning, giving a new meaning to pedagogical practices. (Rodrigues, Leandro, Barros, Braga, Figueredo, \& Pinheiro, 2020).

On August 18, 2020, the Superior Council [CONSUP] endorsed Remote Education [ER] in the period of sanitary emergency related to SARS-CoV-2 for the degree courses offered by the Federal Institute of Education, Science and Technology of Tocantins [ IFTO]. The performance of classes, during the supervised internship, with the group of interns to plan and prepare the internship proposal, pedagogical interventions, regency, holding meetings with the basic education teacher for presentation and necessary adjustments to the internship proposal and didactic pedagogical strategies were carried out by digital means (IFTO, 2020). Ordinance No. 766/2020/REI/IFTO, of August 18, 2020, (IFTO, 2020), approving remote teaching and conducting curricular internship activities supervised by digital means such as: activities in virtual environments for teaching and learning, video classes, web conferencing, social networking sites, instant messaging applications, email, synchronous (local time teacher-student interaction) and asynchronous (no teacher-student interaction at the same time and location) classes.

The Pedagogical Project of the Graduate Course in Chemistry at IFTO mentions the steps that will take place in the Supervised Curricular Internship II.

The Supervised Curriculum Internship II will focus on: Its activities in the 1st grade of high school, in which the intern will make an initial contact for recognition, with the pedagogical team and with the conductor of the class that will supervise him. He will observe the Chemistry classes and prepare the PAE Internship Activity Plan, covering between six and ten hours / assisted conducting class, that is, he will teach classes with the help of the Supervisor Professor (regent); will 
actively participate in projects carried out at the school; and it will record its activities in the partial and final report, relating to the evolution of activities (IFTO, 2020. p. 59).

In the remote stage, the steps to carry out stage II prevail. These steps will be carried out in person, that is, these steps will be carried out using the Technologies and accompanied by an advisor and a supervisor of the internship granting unit who will accompany the interns in the investigation and identification of contents, educational actions in these environments made it possible to production of knowledge about the teaching routine in the different fields of activity of the graduate in Chemistry.

Given the above, this work analyzed the experiences of 20 (twenty) students of the Licentiate Degree in Chemistry, in the 1st semester of 2021, after completing the Supervised Internship II in the context of the pandemic caused by Coronavirus, with the curricular activities developed in the Remote Learning (ER), aiming to investigate the choice of the Chemistry Degree course, conditions of access to Digital Technologies of Information and Communication TDICs, pedagogical tools used during the internship, adversities encountered by these students during the internship and the contributions of remote internship for the formation of the Degree in Chemistry.

\section{Methodology}

\subsection{Type of Study}

Exploratory research was used, from the application of a questionnaire with five questions, presented in Table 1, to the students of the Licentiate Degree in Chemistry at the Federal Institute of Education in Science and Technology of Tocantins - IFTO campus Paraíso do Tocantins, who attended the Supervised Curricular Internship II (ES). Table 1 presents the questions that were answered by the students after completing the Supervised Curriculum Internship II, in the first semester of 2021, in the distance modality.

Table 1 - Questionnaire used in data collection.

\begin{tabular}{ll}
\hline$N^{\circ}$ & \multicolumn{1}{c}{ Questionnaire } \\
\hline 1 & Reason for choosing the Degree in Chemistry. \\
2 & Adversities encountered during the internship. \\
3 & Conditions of access to Digital Technologies of Information and Communication TDICs. \\
4 & Pedagogical tools used during the Supervised Curricular Internship II. \\
5 & Contributions from the remote internship to the formation of the Graduate in Chemistry \\
\hline
\end{tabular}

Source: Authors (2021).

A quali-quantitative approach was used, that is, association of qualitative open questions) and quantitative (closed questions) processes, as there was exposure of quantitative information about the students' responses and also the demonstration of the evaluation of the information (Marconi \& Lakatos, 2015). Qualitative research uses methods that highlight the importance of interpreting the object of analysis, to be performed by the researcher, who interacts with the studies, issuing opinions on the phenomenon under analysis (Pereira et al., 2018). Quantitative type research is related to the quantity that can be tested, verified, tried and measured, as we present statistical calculations, graphs, tables that best demonstrate the results obtained, in an integrated way with the quantitative approach (Costa et al, 2019; Mól, 2017). According to Coutinho (2013), quantitative research highlights observable phenomena in the measurement, behavioral or socio-affective assessment that can be measured, while qualitative research describes the phenomena by words, text, audio, videos instead of numerical data.

\subsection{Location of research}

The study was carried out in the 2nd year of Integrated High School in the Agroindustry, Environment and Informatics Courses of the Federal Institute of Education Science and Technology of Tocantins IFTO: Paraíso do Tocantins campus, located on BR 153, KM 480 - Agro-industrial District in the City from Paraíso do Tocantins, State of Tocantins from 
February to July 2021 during the Covid-19 pandemic.

\subsection{Participants}

The research was carried out with the participation of 20 (twenty) academics of both sexes, aged between 20 and 33 years old, enrolled and concluding the Supervised Curricular Internship II, offered in the Chemistry Degree course at the IFTO campus Paraíso do Tocantins.

\subsection{Data collection instrument and procedure}

Considering the determination of the social distancing imposed by the Covid-19 pandemic, a data collection was carried out using a virtual questionnaire, with objective and discursive questions, created on the Google Forms ${ }^{\circledR}$ digital platform. The link to access the questionnaire was made available in the WhatsApp ${ }^{\circledR}$ group of the Supervised Curriculum Internship II class and returned answered in August 2021. Gil (2008), define the questionnaire as an investigative technique formed by several questions that they are submitted to individuals, who consent to answering the questions, for the purpose of acquiring information.

The data obtained through the questionnaires were submitted to Content Analysis, because, from this type of analysis, it is possible to obtain quantitative indicators. After reading all the answers obtained, the categorization of data was carried out based on similar contents present in the answers, with the aim of understanding more deeply the perceptions and conceptions of trainee students about the object of study of this research.

\section{Results and Discussion}

The analysis of the questionnaire data answered by the students who took the Supervised Curricular Internship II were subdivided into four (5) categories. The first is the evaluation of the choice of the Licentiate Degree in Chemistry, the second access the Digital Technologies of Information and Communication TDICs, the third the pedagogical tools used in the regency, the fourth presents the adversities encountered during the internship, and fifth, the contributions of the remote internship for the formation of the graduate in chemistry. All these situations were expressed below using tables.

\subsection{Reason for opting for the Licentiate Degree in Chemistry.}

Regarding the reasons for choosing the Degree in Chemistry course, Table 2 shows that $40 \%$ of the interns interviewed were motivated to choose the course because they like to teach, like to teach and/or want to be a teacher, which $25 \%$ of students see in graduation one placement in the job market, $20 \%$ chose the night course with the possibility of working during the day, $10 \%$ because of low competition and $5 \%$ because it was the course that I got approval.

Table 2. Reasons for choosing a Degree in Chemistry.

\begin{tabular}{lcc}
\hline Reason for choosing the Degree in Chemistry. & number of students & $\%$ \\
\hline Likes to teach and or wants to be a chemistry teacher. & 8 & 40 \\
Ease of getting placement in the job market. & 5 & 25 \\
Night course with the possibility of working during the day. & 2 & 20 \\
Low competition. & 1 & 10 \\
course I was approved. & 2 & 5 \\
\hline
\end{tabular}

Source: Authors (2021).

With regard to enjoying teaching, academics reported affinity with teaching science, didactics used by their professors when giving classes and practical classes taught in the laboratory as being the elements that influenced the choice of the 
licentiate course. The option of the evening course is the opportunity for the proletariat to have access to university and to attend a higher education course working during the day, without having this possibility to do higher education in the morning or afternoon. Silva, (2020), states that the reasons for choosing the Licentiate Degree in Pedagogy among trainee students during the pandemic: were love (20\%), Identification in the area (20\%) and better financial conditions (15\%). According to Gatti, Tartuce, Nunes, \& Almeida, (2010) students see teaching not as a profession, but as a priesthood, a mission in response to a vocation. Bego \& Ferrari (2018), explain that with regard to the students' job expectations, there is no emphasis on valuing the professional, but rather the fact that it is a craft that provides opportunities for recent graduates to gain jobs more easily due to low demand. and the low number of workers in the area. Gatti \& Barreto (2009), highlights those courses related to the teaching career mainly attract students from lower socioeconomic classes. They also claim that this is due to the fact that teaching makes possible social ascension.

\subsection{Conditions of access to Digital Technologies of Information and Communication TDICs.}

Table 3 shows that undergraduate students accessed TDIC at home $(60 \%)$ or at the home of friends or relatives (30\%), using a smartphone (55\%) or notebook (30\%), through a broadband service $(60 \%)$ or radio (30\%) with good connection quality $(60 \%)$ or regular.

Table 3. Conditions for access to Digital Technologies of Information and Communication TDICs.

\begin{tabular}{lcc}
\hline Internet access. & number of students & $\%$ \\
\hline At home. & 12 & 30 \\
At the home of friends or colleagues. & 3 & 15 \\
At family home. & 1 & 15 \\
At the Lan house. & 1 & 5 \\
Routing from another person or establishments & number of students & \\
\hline Connection quality assessment. & 12 & 60 \\
\hline Good. & 5 & 25 \\
Regular. & 2 & 10 \\
Excellent. & 1 & 5 \\
Bad. & number of students \\
\hline Device(s) used for access. & 11 & 6 \\
\hline Smartphone. & 6 & 55 \\
Notebook. & 2 & 30 \\
Desktop. & 1 & 10 \\
Tablet. & number of students \\
\hline Internet service used. & 12 \\
\hline Broadband. & 6 & 5 \\
Radio. & 2 & 60 \\
Mobile internet device. & 30 \\
\hline
\end{tabular}

Source: Authors (2021).

According to Gonçalves \& Avelino (2020), all students should have access to a quality Internet service in order to access TDICs and carry out the remote internship. 'According to the Brazilian Institute of Geography and Statistics [IBGE] (2020), 21.6\% of Brazilians do not have internet access and the cell phone is used by $99.2 \%$ of Brazilian households, being one of the predominant means of connection with internet used by the population.

According to a survey carried out by Cigales \& Souza (2021), seeking to know which technological instruments most used by students to study, they highlighted: the notebook $90.7 \%$, followed by the cell phone, with $86 \%$, the desktop computer and the tablet, each. with $11.6 \%$. Also, according to the authors' research, $97.7 \%$ of the students had internet at home, $55.8 \%$ 
said they had enough internet to carry out activities, $32.6 \%$ said that the internet had fluctuations that would compromise the performance of activities, and only $11.6 \%$ said they had a great connection quality.

Access to good quality internet service, as well as the use of equipment are essential factors for carrying out the activities of the remote internship of students of the Chemistry Degree, as it is necessary to ensure access, to all students, of good quality in order to can perform the activities remotely (Cigales \& Souza 2021).

Thus, for the remote internship to be carried out, financial support, internet infrastructure and computers are needed for students in isolation.

\subsection{Pedagogical tools used during the internship.}

Table 4 shows that 55\% of interns used Google Meet. 25\% Whatsapp and 20\% the VLE virtual learning environment as pedagogical tools during the remote internship.

Table 4. Pedagogical tools used during the remote internship.

\begin{tabular}{lcc}
\hline Pedagogical tools used during the remote internship. & number of students & $\%$ \\
\hline Google Meet. & 11 & 55 \\
WhatsApp. & 5 & 25 \\
Virtual Teaching Environment (AVA). & 4 & 20 \\
\hline
\end{tabular}

Source: Authors (2021).

Teaching and, consequently, supervised curricular internships had to undergo modifications to adapt to virtual environments. Soberay \& Freitas (2021) states that the supervised curricular practices of the internship in formal and nonformal spaces allow a restructuring, via virtual environments, recording video classes, using videoconferencing systems, such as Google Meet ${ }^{\circledR}$, Zoom $^{\circledR}$, Skype ${ }^{\circledR}$, Facebook ${ }^{\circledR}$, Hangout ${ }^{\circledR}$ or learning platforms such as WhatsApp ${ }^{\circledR}$, Google Classroom ${ }^{\circledR}$, Moodle $^{\circledR}$, and Microsoft Teams ${ }^{\circledR}$. The Supervised Curricular Internship had to be adapted to the virtual teaching environment. In this new context, education is challenged to create new teaching relationships in the educational environment, mediated by TDICs, restructuring of the modus faciendi teachers and students, new perspectives on pedagogical work, digital platforms and methodological changes (Gonçalves \& Avelino, 2020). Rondini et al. (2020) point out that the changes in the educational system, implemented quickly, required teachers to adapt and transpose in-person classes to online platforms, with the use of TDIC, causing impacts on supervised curricular internships.

\subsection{Adversities encountered during the internship.}

According to Table 5, the most relevant problems detected by future teachers during Supervised Internship II were internet access (30\%), lack of knowledge in digital media (20\%) and adaptation to remote classes (15\%).

Table 5. Adversities found during the internship.

\begin{tabular}{lrc}
\hline Adversities encountered during the internship. & number of students & $\%$ \\
\hline Internet access. & 6 & 30 \\
Lack of knowledge in digital media. & 4 & 20 \\
Adaptation to remote classes. & 3 & 15 \\
Difficulty in recording classes. & 5 \\
Difficulty in content. & 1 \\
Reconcile the internship with working hours. & 1 \\
Nervousness in the first regency and monitoring. & 1 \\
Class preparation. & 1 \\
Little guidance. & 5 \\
Lack of interaction with students and with the daily life of the school environment & 5 \\
\end{tabular}


Hegeto \& Lopes (2021) highlight difficulties, in the context of the COVID-19 pandemic, faced by students in the use of online teaching platforms, whether due to lack of knowledge, lack of compatible equipment or difficulties in accessing the internet in the remote stage. According to Silva (2020), the problems mentioned by students occur because of relevant disciplines for the training of future teachers, providing little or no contribution in the practical pedagogical context developed at the school, which can lead to ineptitude or insecurity in the student. The author also states that the social isolation imposed by COVID-19 cooperated so that the adversities during the internship were more apparent, both because of the inexperience of teachers and students with the remote internship and because of the psychological distress caused by the disease.

Soberay \& Freitas (2021), emphasizes the impossibility of financial resources to provide credit on cell phones, social distance preventing access to other homes in the midst of the pandemic crisis and the distance of access areas in relation to their homes as difficulties for maintenance online during the synchronous classes of the remote stage. The authors emphasize the importance of preparing students for the use of platforms and suggestions for using them as a pedagogical tool during internships.

According to Gonçalves and Avelino (2020), the difficulties caused by inexperience or lack of knowledge in digital media are created by the limitation of traditional classes given before the pandemic imposed by COVID-19.

Lohmann \& Venturi (2020), highlights that the remote stage provoked important reflections and required changes in habits and behaviors to adapt to the use and mastery of Digital Technologies of Information and Communication. Adapting to the new teaching methodology is a necessity and requires knowledge of technological resources for transmitting and obtaining information. The experience of lack of quality access, internet or electronic equipment, inexperience in the use of TDIC by many interns, collaborate with the difficulties of using this new teaching modality in the remote internship.

\subsection{Contributions from the remote internship for the formation of the Graduate in Chemistry.}

According to Table 6, when asked about the contribution of remote internship to professional training, 35\% of students said that during the remote internship they learned and used several technological resources, $20 \%$ used new digital technologies for teaching and $15 \%$ answered that used digital platforms.

Table 6. Contributions of the remote internship for the formation of the Graduate in Chemistry

\begin{tabular}{|c|c|c|}
\hline Contributions from the remote internship to the formation of the Graduate in Chemistry & number of students & $\%$ \\
\hline Learning and using different technological resources. & 7 & 35 \\
\hline Use of new digital technologies for teaching. & 4 & 20 \\
\hline Digital platform use. & 3 & 15 \\
\hline New perspective on teaching modalities. & 1 & 5 \\
\hline Changing paradigms in the operationalization of teaching. & 1 & 5 \\
\hline Expansion of learning, through the confrontation between theory and practice. & 1 & 5 \\
\hline Guidance for teaching. & 1 & 5 \\
\hline Criativity and innovation. & 1 & 5 \\
\hline New look at educational practice. & 1 & 5 \\
\hline
\end{tabular}

Source: Authors (2021).

Amidst the challenges caused by the health crisis caused by the COVID-19 pandemic, which caused isolation and social distancing, destabilizing the educational system in Brazil, the experiences lived in the remote stage provided opportunities for new reflections on teaching practice. Students consider the practices experienced and their contributions during the remote internship to be relevant. The Supervised Curricular Internship II held remotely was essential and contributes to the initial training of future chemistry teachers, providing the construction and reorganization of scientific knowledge in a gradual and significant way, exercising research, reflection and learning and use of various technological 
resources (Cantoni et al, 2021). The internship narrows the distance between the reality of the school environment and the student, promoting an inseparability between practice and theory through didactic experiments and methodologies, building new knowledge and technical scientific knowledge (Marques, 2021). Resolution No. 2 of 2019 of the National Curriculum Guidelines for Initial Teacher Training for Basic Education defines that the licensee must operate digital information and communication technologies, virtual contents and other technological resources and integrate them into pedagogical practice, enhancing and transforming the learning experiences experienced by students and promoting investigative behavior (BRASIL, 2019, p. 17).

According to Ferraz \& Ferreira (2021), the pandemic caused by COVID 19 taught students and teachers to give new meaning to classes, teaching practices and knowledge and teaching. Also, according to the authors, to innovate remotely, developing multiple perspectives and instruments for the classroom, adjusting old methodologies to new tools, taking advantage of all the knowledge used in the remote stage for future application in the classroom (Ferraz \& Ferreira, 2021).

\section{Conclusion}

The work analyzed the experience of 20 students of the Licentiate Degree in Chemistry during the Supervised Curricular Internship II in the 1st semester of 2021 during the pandemic caused by Covid-19. For a better understanding of how the Remote Internship (RE) occurred, aiming to investigate the choice of the Chemistry course, the conditions of access to TDICs, Digital Information and Communication Technologies, pedagogical tools used during the internship, adversities encountered by these students during the internship and the contributions of the distance internship for the formation of the Post-Graduate in Chemistry. The research carried out will contribute to the reflection on the new context of distance education and the role of the intern in Basic Education. This will also allow actions to carry out future internships in this new context of teaching and learning.

According to the specific objectives proposed in the research, we present the following results: the students chose a degree because they like to teach and because of their insertion in the job market, they accessed digital technologies at home, using smartphones through a broadband service with good quality of life. connection, used Google Meet ${ }^{\circledR}$, Whatsapp ${ }^{\circledR}$ and VLE virtual learning environment as pedagogical tools during the internship, internet access, lack of knowledge in digital media and adaptation to remote classes were the adversities encountered during the internship and learning and use from several technological resources, and digital platforms the contributions of the internship to its formation.

The virtual remote internship enabled and provided opportunities for varied everyday experiences, promoting reflection on teaching work. The contribution to the construction of knowledge about the remote internship experienced by interns during the second stage of teacher education evidenced the reconstruction of teachers' knowledge and a redefinition of teaching and learning practices.

\section{Acknowledgments}

To God, to the Federal Institute of Education, Science and Technology of Tocantins (IFTO) campus Paraíso do Tocantins for the support given during the development of the stages of this work.

\section{References}

Bego, A., M., \& Ferrari, T., B., (2018). Por que escolhi fazer um curso de licenciatura? perfil e motivação dos ingressantes da UNESP. Química Nova, 41(4), 457-467. https://doi.org/10.21577/0100-4042.20170159.

Bezerra, J. I. S., \& Fonseca, G. F. (2018). The education psychology and the interfaces with the educational formation: an analysis of the supervised stages. Research, Society and Development, 7(6), e1376363. https://doi.org/10.17648/rsd-v7i6.363 
BRASIL. Ministério da Educação. Resolução N. ${ }^{2}$ 2, de 20 de dezembro de 2019. Define as Diretrizes Curriculares Nacionais para a Formação Inicial de Professores para a Educação Básica e institui a Base Nacional Comum para a Formação Inicial de Professores da Educação Básica (BNC-Formação). http://portal.mec.gov.br/docman/dezembro-2019- pdf/135951-rcp002-19/file.

Cantoni, J., Rochembach, E. S., Chiapinoto, M. L., Lauxen, A. Antonio. (2021). Estágio Curricular Supervisionado: perspectivas e desafios de constituir-se educador em tempos de pandemia. Revista Insignare Scientia. 3(4). https://doi.org/10.36661/2595-4520.2021v4i3.12130

Cigales, M. P., \& de Souza, R. D. (2021). O Estágio Curricular Supervisionado em tempos de pandemia: um debate em construção. Latitude, 14(Esp.), 286310. Recuperado de https://www.seer.ufal.br/index.php/latitude/article/view/11400

Costa, P. M. S., Araújo, A. C. L., Moreira, D. N., \& Geglio, P. C. (2019, 5 a 9 de novembro). O estágio curricular na concepção dos estudantes dos cursos de licenciatura em química: uma análise das respostas ao questionário do ENADE. [Apresentação de trabalho]. Anais do 59 Congresso Brasileiro de Química. João Pessoa. Brasil. http://www.abq.org.br/cbq/2019/trabalhos/6/1942-27643.html

Coutinho, C. P. (2013), Metodologia de investigação em ciências sociais e humanas: Teoria e Prática. 2. ed. Coimbra: Edições Almedina.

Ferraz, R. D., \& Ferreira, L. G. (2021). Estágio supervisionado no contexto do ensino remoto emergencial: entre a expectativa e a ressignificação. Revista de estudos em educação e diversidade - REED, 2(4), 1-28. https://doi.org/10.22481/reed.v2i4.8963

Gatti, B. A.; Tartuce, G. L. B. P.; Nunes, M. M. R.; Almeida, P. C. A. (2010). (coord.); In Estudos e Pesquisas Educacionais, nº 1 , Fundação Victor Civita: São Paulo. 139-210

Gatti, B. A., Barretto, E.S.S (2009). Professores: aspectos de sua profissionalização, formação e valorização social. Relatório de Pesquisa, DF:UNESCO.

Gil. Antônio Carlos. (2008) Métodos e técnicas de pesquisa social. 6. ed. São Paulo: Atlas.

Gonçalves, N. K R., \& Avelino, W F. (2020). Estágio supervisionado em educação no contexto da pandemia da COVID-19. Boletim de Conjuntura (BOCA), 4(10), 41-53. http://dx.doi.org/10.5281/zenodo.4022983

Hegeto, L. de C. F., \& Lopes, D. C. (2021). Desafios do Estágio obrigatório em tempos de pandemia. Cadernos De Estágio, 3(1), 172-183. https://periodicos.ufrn.br/cadernosestagio/article/view/25936

IBGE. Instituto Brasileiro de Geografia e Estatística (2020). Acesso à Internet e à televisão e posse de telefone móvel celular para uso pessoal 2018. https://biblioteca.ibge.gov.br/visualizacao/livros/liv101705_informativo.pdf.

IBGE. Instituto Brasileiro de Geografia e Estatística (2020). Acesso à Internet e à televisão e posse de telefone móvel celular para uso pessoal 2018. https://biblioteca.ibge.gov.br/visualizacao/livros/liv101705_informativo.pdf.

IFTO. Instituto Federal de Educação Ciência e Tecnologia do Tocantins (2020). Projeto Pedagógico do Curso de graduação em Licenciatura em Química. Paraíso do Tocantins. http://www.ifto.edu.br/ifto/colegiados/consup/documentos-aprovados/ppc/campus -paraiso-do-tocantins/licenciatura-em-quimica/ppclicenciatura-em-quimica-campus-paraiso-do-tocantins.pdf

IFTO. Instituto Federal de Educação Ciência e Tecnologia do Tocantins (2015). Regulamento do estágio curricular supervisionado dos cursos de graduação presenciais do Instituto Federal de educação, Ciências e tecnologia do Tocantins. http://portal.ifto.edu.br/palmas/campuspalmas/ensino/estagio/normativa/regulamento -estagio-supervisionado-cursos-graduacao-presenciais-ifto2edicao.pdf/view

Lorenson, G. A., Pereira, G. A., \& Mariano, N. M. (2020). The use of the game in the teaching and learning process of the periodic table: evaluation of a regence stage intervention in chemistry. Research, Society and Development, 9(8), e47985324. https://doi.org/10.33448/rsd-v9i8.5324

Lohmann, L. A. D., \& Venturi, T. (2020). O estágio supervisionado em ciências de forma remota durante uma pandemia. In: Simpósio Sul-Americano de pesquisa em ensino de ciências, n. 1, 2020, Cerro Largo. Anais [...]. Cerro Largo: UFFS, 2020. https://portaleventos.uffs.edu.br/index.php/SSAPEC/article/view/15021.

Manara, A. S., Marzari, M. R. B., \& Ruppenthal, R. (2021). Student-teacher: resigning knowledge through the path and perception of the supervised curriculum internship. Research, Society and Development, 10(11), e562101120017. https://doi.org/10.33448/rsd-v10i11.20017

Marconi, M. A., \& Lakatos, E. M. (2015). Fundamentos de metodologia científica (5 ${ }^{\text {a }}$ ed.). Atlas

Marques, A. C. T. L. (2021). Estágio e Formação de Professores: um diálogo com Freire. Revista Hipótese, Itapetininga, 7(único), 113 - 133. https://drive.google.com/file/d/1vXbGstREVnuoHoXxO2Afl-yKQowrcoc_/view

Mól, G. S. (2019). Pesquisa qualitativa em ensino de química. Revista Pesquisa Qualitativa, 5(9), 495-513. https://editora.sepq.org.br/rpq/article/view/140/96

Moreira, J. A. M., Henriques, S., \& Barros., D. (2020). Transitando de um ensino remoto emergencial para uma educação digital em rede, em tempos de pandemia. Dialogia, (34), 351-364. DOI https://doi.org/10.5585/dialogia.n34.17123.

Pereira, J. A., \& Leite, B S. (2021). Percepções sobre o aplicativo FOQ1 química por estudantes de uma escola pública. Revista REAMEC, 9(1). e21001. https://doi.org/10.26571/reamec.v9i1.11227

Pereira, A. S., Shitsuka, D. M., Parreira, F. J., \& Shitsuka, R. (2018). Metodologia da pesquisa científica. Editora UAB/NTE/UFSM

Rodrigues, L. G., Leandro, C. dos S., Barros, F. B. de, Braga, I. H. T., Figuerêdo, J. E. da S., \& Pinheiro, A. de A. G. (2020). Distance Education, remote teaching and new educational information and communication technologies in a pre and post-pandemic scenario. Research, Society and Development, 9(11), e51191110168. https://doi.org/10.33448/rsd-v9i11.10168

Rondini, C. A. Pedro, K. M., \& Duarte, C. dos S. (2020). Pandemia da covid-19 e o ensino remoto emergencial: mudanças na prática pedagógica. Interfaces Científicas, 10(1), 41 - 57. https://doi.org/10.17564/2316-3828.2020v10n1p41-57 
Research, Society and Development, v. 10, n. 15, e443101523260, 2021

(CC BY 4.0) | ISSN 2525-3409 | DOI: http://dx.doi.org/10.33448/rsd-v10i15.23260

Santos, V. H. P. de M. dos, \& Souza, T. B. de. (2020). The supervised internship as space for reflection on teaching practices in the initial training of chemistry teachers at Federal Institute of Rio de Janeiro (IFRJ)-Nilópolis. Research, Society and Development, 9(9), e391996918. https://doi.org/10.33448/rsd-v9i9.6918

Silva, A., M., C., E. (2020). As contribuições do estágio supervisionado na formação docente em tempos de pandemia. Revista multidisciplinar Infinitum. 3(5). http://www.periodicoseletronicos.ufma.br/index.php/infinitum/article/view/15001/8855.

Soberay, S. T. M., \& Freitas, L. G. de. (2021). Ensino remoto emergencial e o estágio supervisionado em educação em tempos de pandemia da covid19. Revista De Estudos Em Educação E Diversidade - REED, 2(4), 1-27. https://doi.org/10.22481/reed.v2i4.8318

Souza, E. M. de F., \& Ferreira, L. G. (2020). Ensino remoto emergencial e o estágio supervisionado nos cursos de licenciatura no cenário da Pandemia COVID 19. Revista Tempos e Espaços em Educação, 13(32), 1-19. https://doi.org/10.20952/revtee.v13i32.14290

Viroli, S. L. M., Medeiros, G. H. de., Carvalho, N. P., Alves, T. T., Souza, K. de J., Sousa, Y. P., Jesus, R. S. de, Araújo, T. L., Lança, A. C., Silva, F. de P. e, \& Ramos, M. L. (2021). The Supervised Internship I in the conception of the Chemistry Degree students: Analysis of the responses to the Curriculum Internship Supervision questionnaire. Research, Society and Development, 10(10), e168101018695. https://doi.org/10.33448/rsd-v10i10.18695

Yamaguchi, K. K. de L. (2021). Ensino de química inorgânica mediada pelo uso das tecnologias digitais no período de ensino remoto. Revista Prática Docente, 6(2), e041. https://doi.org/10.23926/RPD.2021.v6.n2.e041.id998 